\title{
METHOD AS RUSE: FOUCAULT AND RESEARCH METHOD
}

Wigmore, John H. 1937. "Roscoe Pound's St. Paul Address of 1906; The Spark that Kindled the White Flame of Progress." Journal of the American Judicature Society 20(5):176-178.

Yntema, Hessel E. 1960. "American Legal Realism in Retrospect." Vanderbilt Law Review 14(1):317-330.

\section{Marvin L. Cooke \\ Tulsa Junior College}

Mid-American Review of Sociology, 1994, Vol XVIII, No. 1 \& 2: 47.65

A ruse is a gimmick or device used as a strategy or instrument. For Foucault, method can best be understood as a ruse rather than as a method which promises truth. Methods regulate what can be discovered and the discourse about what can be discovered. In this essay, the realist and idealist models of meshod are criticized from Foucault's perspective. Both models rely on some transcendental reality which -- from Foucault's perspective -are constructed by the practices of research itself. Even though Foucault rejects foundational assumptions, he does have a method which has its homogeneity, its systematicity, and its generality. Foucault's method is outlined, discussed, and related to similar methods. Finally, Foucault's critics are noted and answered.

Method in most social science is built on either the realist or the idealist model of epistemology (Smith 1983; Smith and Heshusius 1986). The realist model assumes a social reality independent of the knower that can be know if only the knower can be divested of values, that is, if the knower can be objective. Thus, the realist utilizes randomization, blind tests, the null hypothesis, the separation of the researcher from the subject, and numerous other devices practically to force a separation of fact and value in the practice of knowing. Claims about social reality which do not utilize such practices are criticized as being conditioned or biased by the values, emotions, or interests of the knower.

The idealist model assumes that knowing cannot be separated from the knowing subject. Regardless of practices used to separate the knower from sources of hias, the knower always actively selects theories, methods, and interprelations. Thus, fact can never be separated from value. For the idealist, one uses one's own capacity for understanding to attempt to understand the meaning that others give to situations. Since the subject in the only one who can confirm or modify a researcher's understanding of the subject, the independence of the subject and the knower from coercion is fundamental to the process of intersubjective understanding.

Both the reaslist and the idealist models represent a solution to Kant's question, "What is enlightenment?" (Kant 1963). As Gutting (1989) notes:

His famous answer was that enlightenment is man's release from his "inability to make use of his understanding without direction from another." an inability that was to be overcome by finding the courage to use one's 
own reason rather than submit it to books, pastors, physicians, and other external authorities.

The realist strategy to make use of understanding without direction from another is to develop and use practices that eliminate the influence of emotions, values, is to develop. and interests. The idealist strategy to make use of understanding with to the direction from another revolves around strategies to giver, other researchers, and interpretations of the subject being studied, the researcher, other researchers, and the reader of the research product.

Foucault $(1965,1972,1975,1979,1980,1982 a, 1982 b, 1984,1988 a$, Fondered both of these 1988b. 1988c, 1990a, 1990b, 199 the objective nature of the real and the perspectives problematic by showing that the subject are both built on particular, independent, meaning giving nature of the subject are both buill on particular, historical practices that are not power neutral. In other words, the very strategies used by the realist and the idealist models to make use of underst

direction from another are in fact replete with effects that direct.

The purpose of this work is to critically evaluate the realist and idealist approaches to research method from Foucault's viewpoint and to outline elements of Foucault's own approach to method. First, the realist model of elemearch will be elaborated and criticized with respect to the model's assumptions research will be elaborate relation between the knower and the known, an of a neutral, objective relation between the knower ans can be judged, a independent source of reality against which one's models can be judged, a universal reality, a unique mapping of reality, of causality. and the universal rence theory of truth. Then, the idealist model of research will be correspondence theory of truth. Thesect to the model's assumptions of a elaborated and criticized with respect to the model's ans ethical subject. transcendental subject as giver of meaning and a transcendental ethical subject. transcendental subjectitional approaches to research method, Foucault's antiAfter criticizing traditional approaches to research methou, Foucault rejects foundational assumptions, he does have a method which has its hom systematicity, and its generality. After elaborating Foucault's method and relating it to the grounded theory approach to qualitative research and the relating it to the grounded the study of organizations, Foucault's critics will be noted and answered.

\section{A Critique of the Realist and Idealist Epistemologies}

The aim of the realist model (Smith 1983; Smith and Heshusius 1986) is to The aim of the realist moded (Smith to the actual conditions of the world. match one's descriptions of the wortd reality against which one's models can be Here, there is an independent source of reality against which one's models can independently existing reality, the knower must be neutral. Thal is, the knower must eliminate all bias and preconceptions, must not be emotionally involved in the knowing process, and must use value-free, neutral language. Devices used to the knowing process, and insure and measure reliability, internal validity, and external validity ants
procedures used to eliminate bias and preconceptions. If contradictory statements arisc, the existence of an independent reality provides a point of comparison and arbitration against which contradictory statements about the reality can be adjudicated. By using the appropriate procedures, one should be able to develop and refine laws of association and causal laws which are isomorphic with reality.

While the realist view of social science posits a distance between the knower and the known, Foucault's (1979) analysis of the application of discipline in the prison reveals immediately that the neutral, objective relation between the knower and the known assumed by the realist model rests on devices such as hierarchical observation, the panoptican, and the examination. The neutrality and objectivity assumed is crealed by these asymmetric devices. Thus, they are not neutral. Similarly, Emerson (1988) exposes this use of power relations to creale objeclivity in his analysis of the emergence of self-consciousness in field work. Colonial regimes in which much early field work was conducted was built on the power relation between the colonial rulers and the native population. The power of the ruler guaranteed access to and cooperation from the natives. Thus, conditions could be manipulated to test hypotheses. The power and cultural differences between the colonial researcher and the natives provided the exterior, detached subjects necessary for the construction of the appearance of neutrality and objectivity. Yet, this again. is hardly a neutral situation. In a different vein, Duncan (1984) notes that most methods of measurement in the realist model of social science have their social roots in methods of voting levying taxes, valuing goods, labeling social ranks, bestowing honors, and drawing lots. Again, all of these are rooted in nonneutral, asymmetric relations.

A second line of criticism of the realist model can be drawn from Foucault's critique of the foundationalist notion of an independent, knowable reality. Cooke (1993a) observes that, while Foucault avoids solipsism by the minimal realism of recognizing sources of recalcitrance and asymmetries set up by other practices, Foucault is unwilling to privilege any model of reality as true because there is no way to separate knowledge from the asymmetries of the practices used to find truth. For example, Alwin and Krosnick (1985) observe that the ranking of values is altered by the use of a rating or a ranking methodology. Is the difference they found rooted in the method, did they discover two different aspects

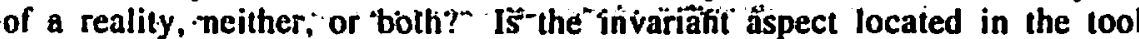
constructed to produce a measure or in some reality independent of the tool? Similar questions can be raised about Smith's (1987) finding that attitudes toward a public policy change when survey respondents are asked questions using the word "poor" instead of "welfare." One can describe the apparatuses and resistance involved in social action and the consequences associated with those apparatuses and resistance. But, can one claim a truth transcendent of this codetermined situation?

A third line of criticism of the realist model is suggested by Foucault's (1980) criticism of global, totalitarian theories. The realist model assumes that there is one, universal reality that one can discover and reduce to laws of association or causation. While these global theories have provided useful tools for local research, the very notion of global theories forces all local, non- 
centralized practices either into a common mold or discounts them as accidental and therefore inadequate.

One way the ideal of universal reality is operationalized in realist models is through sampling theory. The traditional sampling approach assumes that a set of practices would be distributed in a normally distributed fashion. There are statistical test for testing this assumption. Basically, these tests are devised by constructing a normally distributed population, by drawing a random series of samples of a specific sample size, and by developing a distribution of a specific parameter such as standard deviation. These tests assume a condition and use it to construct a conditional statement: If the population is normally constructed, then any sample of a given size should fall within a given parameter with a given probability. Even though every student of logic and scientific method knows that this scheme guarantees nothing because the converse of a conditional statement is not necessarily true, the practical use of the test is to rely on the truth of the converse. Unless one can survey all practices over all time under consideration, one is left with the assumption of the nature of the distribution of practices. Thus, with sampling, explanation - a theory about the nature of the population - precedes discovery and establishes -- i.e., governs -- the discourse about it.

A second assumption of traditional sampling is that one has the apparatus available to obtain a random sample. That is, it assumes that one has the power to gain access to get a sample which is representative of the population as theorized. However, if one is studying an organization, one will be embedded in numerous practices which direct, block, and reorganize that to which one can gain access. For example, a company that Cooke (1993b) studied employed a management consulting firm to survey all of the employees in the organization. To get the surveys completed, the company had to require as well as to encourage employees to take the survey. In response to this, he found that several employees cooperated to answer questions the same to "send a message" to management. Others collectively decided to answer neutrally to "hide" in fear of the consequences if they revealed their true feelings. So, the tactics adopted by the respondents rendered the total population survey problematic by introducing totally unknown characteristics into the population from -trosetheorized. Here, no a priori construction of the population could have included the practices actually used by workers because the workers devised the practices in response to the survey.

A fourth line of criticism of the realist model can be constructed by contrasting Foucault's anti-essentialist, "polymorphous" approach to correlation with the essentialist, exclusive partitioning approach to causality. First, the normal way of doing social science relies heavily on the requirements from logic that reality be partitioned into mutually exclusive categories based on an essential aspect of the phenomena under consideration. This might be done through such devices as ideal types (Weber [1958] 1978), categories (Strauss, 1987: Charmaz, 1988), or definitions (Best 1981; Babbie 1986). Foucault (1991b) criticizes such a partitioning and reducing because such categories are created by the researcher in order to reduce potentially important differences into commonalities. Such reductions further become a priori judgments which restrict the field of consideration of the researcher. While it is never possible to know if one has enumerated all elements of a practice, normal social science presupposes such a possibility. Furthermore, the categories are probably not present in the thought of the individuals whose concrete behavior is to be understood on their bases. Finally, definitions, categories, and rationalities are all parts of practices whose power effects can be understood only by relating them to other elements of practices.

In the place of essential reduction, Foucault (1991a, 1991b) encourages one to break down practices into their elements. While one attempts to "saturate" the break down and while the elements can be taken as finite, one can never presume to know that the break down is complete. Furthermore, the breakdown is a construction of the researcher. Thus, one cannot claim to exhaustively or essentially categorize some reality.

Second, ideas of causality in naturally occurring settings rely on the conditional statement and on some accounting of covariation. As noted earlier, conditional statements only give one the ability to reject some theorized necessary condition. They cannot be used to affirm necessary conditions without relying on the practice of affirming the converse of the conditional, which is a fallacy within the discourse of conditional statements. When it is applied to an accounting of covariation, the slope becomes even slicker. Whether one uses cross classification, correlation, regression, factor analysis, or some other measure of covariation, the procedure forces a reduction of phenomena to the variables under consideration and constructions an accounting of variation in the dependent variable in terms of the currency of the independent variables.

To demonstrate the indeterminacy of conjecturing relations between variables and then using covariation to demonstrate the relation, consider Cooke's (1992) examination of the relationship between relative cohort size of persons in an internal labor market and the rate of survival of members of a cohort in an organization from one time period to another. Cooke used Reed's (1978) findings that an individual's chances for promotion are greatly affected by - Telative cohort size in a system in which all promotions are made from within and in which few leave for other employment to predict that, as the ratio of younger to older clergy rises, the number of younger clergy remaining in the ministry in the next period will decrease. When Cooke examined this relationship for all members of the Oklahoma Annual Conference of the Methodist Church who were in the ministry from 1940 to 1980 , he found the predicted linear relationship between relative cohor size and survival in the ministry that accounted for forty-four percent of the variation in the proportion of clergy surviving to the next period. However, when he considered only clergy who were actually in the internal labor market of the annual conference, the predicted linear relationship only accounted for one percent of variation in the proportion of clergy surviving to the next period. So, by changing definitions .which were all mutually exclusive within their scheme -- one came up with 
different results. While the discourse of causality would cause one to begin to look for other variables, one is always left in the position of not knowing if one has enumerated all elements or if one has appropriately related the elements as one forces the accounting of variation into the enumeration one has created with a discourse about causation which claims more than it can ever deliver.

In the place of allocating causality on the basis of classification and variation accounting, Foucault (1991a, 1991b) relies on exploring the interplay and relation of elements of practices and how they posit and work on things, actions of others, and relations with oneself. For example, Foucault (1975, 1991a) notes that a medical object that was positioned on a surface classification is mapped out in the three dimensional space of the body after the beginning of the nineteenth century. The body only becomes a thing to be acted on when it is appropriately identified by a practice. In the practice of discipline (Foucault, 1979), movements become elaborated and codified. Actions can only be acted on once they are elaborated and embedded in a practice. In the confession (Foucault, 1990a), the confessor can only work on a subject once a generalized "desire" has been attributed to the subject.

Once one has identified the elements of a practice and the things, actions of others, and relations with oneself related to the elements of a practice, one can explore ". . . the connections, encounters, supports, blockages, plays of forces, strategies and so on which at a give moment establish what subsequently counts as being self-evident, universal, and necessary" (Foucault 1991b: 76). Foucault intends to substitute this necessarily incomplete exploration of dependencies among elements of a practice and how they posit and work on things, the actions of others, and relations with oneself for the activity of allocating causality. By doing so, Foucault does not claim a better argument for causality. Instead, he intends to explore how practices work while suspending the privilege of arguing cause.

A fifth line of criticism of the realist model is suggested by Foucault's (1980 1984) analysis of truth. As noted earlier, the realist model is built on the correspondence theory of truth. Here, there is a source of reality against which contradictory models can be judged and which can be known by using methods which guarantee-objectivity and neutrality. However, Foucault claims that truth is " ... a system of ordered procedures for the production, regulation, distribution, circulation, and operation of statements" (Foucault 1980: 74). Truth is what is produced by a set of rules and procedures. That is, the rules for producing truth have a power effect by governing which statements are acceptable or unacceptable (Foucault 1984).

To see how the assumptions of the realist position have an effect on governing the acceptability of statements, consider Smith and Heshusius' (1986) analysis of how attempts to adopt realist concerns to idealist methods subvert the aim of the idealist epistemology. Since the idealist model of knowing recognizes that the mind with its attending emotions and intentions is involved in the construction of reality in investigation, inquiry can only be a never ending process of interpretation. "All that can be done is to match descriptions to other descriptions, choosing to honor some as valid because they 'make sense, given onc's interesis and purposes" (Smith and Heshusius 1986:9). If one applies the alims of the realist model Io idealist methods -- which are methods designed to gel al the meaning of things as the other sees it -- one subverts the indeterminism of the idealist epistemology with the determinism of realism. The realist rejuirements of isomorphism between data and an independent reality is imposed on the idealist model such that the codetermination of interpretation is broken apart into subject and ohject. Now, interprelations can be judged by an isomorphism between the researcher's interpretation and the subjecl's interpretation. For example, Agar (1988) and Denzin (1983, 1989a, 1989b) propose that the validity of interpretations can be determined by submitting the interpretations to review by those being studied or by using the interpretations as a rule book to anticipate interaction with the subjects being studied. Another strategy for breaking apart the codelermination of the interpretation with realist assumptions is analytic induclion (Agar 1986; Denzin 1989h). Herc, one creates an interprelation, checks it against further examples of the hehavior under study, modifics the interpretation, checks it against more examples of bchavior, and conlinues until the interpretation can account for all behavior and until no further examples can be found which would counter the interpretation. As Smith and Heshusius (1986) arguc, the application of a realist set of rules for determining truth to a sct of procedures which do not assume an independent reality force the creation of an independent reality and force the separation of the true from the false on the basis of that independent reality rather than by "honoring" some interpretaltions and not others as "making sense."

The idealist model of research (Smith 1983; Smith and Heshusius, 1986) does not posit a strict separation of the knower from the known. It does not posil an independent reality which can be know by a neutral observer. Insiead, the idealist epistcmology recognizes that the object of study is not known apart from the knowing subject. What is known is a product of the mind with its altendant cmotions and values. There is no independent reality available as an arhitrator of interprelations. The process of understanding involves a constant movement with no beginning or ending. Since the viewpoint of the other in social context is the ohject of study, one attempts to understand the meaning that others give to their siluations.. Here, truth can only, be understood as a socially and historically conditioned agreement. With no external reference, two contradictory interpretations are simply different ways of constituting reality. Agrecment is reached through a process of justification that is inescapably hound up with values and interests. All one can do is match interprelations to other interprelations and choose to honor some as valid because they make sense given onc's interests and purposes. There are no rules or procedures to produce truth.

Before moving to criticize the idealist epistemology from Foucault's perspective, it is important to note that Foucault and the idealist epistemology both sec phenomena as constituled in a codetermined fashion with the act of knowing. Thus, hoth are unwilling to engage in claims of procedures which offer to produce truth independent of the practices of knowing. In this way, they 
Mid-American Review of Sociology

both break the social and rhetorical power of truth claims rooted in the realist epistemology.

Having recognized this affinity between Foucault and the idealist epistemology, there are significant and critical differences between them. First, the subject or mind exists for the idealist as a real, transcendental reality that acts to give meaning. As such, it is an unmoved mover which can be an object of study (Cooke, 1993a). Thus, Denzin (1990) notes that undernealh the textual orders created hy social scientist, journalist, or novelist, there is the subject -the man, woman, or child -- who has her or his words and stories to tell. Here, the rescarcher aims to see the world of a group as a member would see it, to learn the meaning of actions from the viewpoints of members, and to portray these as accurately as possible (Smircich 1983). As noted earlier, the riain congruence set up by this scheme is between the interpretations of those studied and the interprelations of the researcher (Jones, 1983). Against the Iranscendental subject, Foucault (1990a) argues that the subject is constructed by techniques used to elicit hidden truth Jrawn from the confessional. As Denzin (1990) observes, the meaning of experience is in its telling. Such meaning itself eludes the leller and listener. But, as Foucault (1990a) notes, the telling is elicited by specific techniques and in specific relations of power. The telling itself elicits further interpretation and emotions by the listener and by the teller alier the fact. The transcendental fiction called subject is an artifact posited by techniques or rituals of relating and by the myths about the situation. Thus, Foucault encourages one to examine the relations, rules, and techniques for interacting rather than subjects themselves to understand what people do and how they do it.

In addition to the subject as the transcendental author of meaning, the idealist epistemology contains a concept of the subject as a transcendental ethical subject. For example, Denzin (1990) posits the right of the subject to interpret his or her own story. Hahermas (1984) posits an equal right among story tellers. Yet, Foucault $(1980,1984)$ argues that such rights are a part of echnologies of sovereignty. While the king gives up certain rights with the concept of natural rights, natural rights ensnare actors in asymmetric devices such as contracts, bureaucracies, and different methods of voting. Rather than constructing a place of freedom to act, natural rights are techniques of governing. In addition. Foucault (1980, 1984) objects to concepts of power grounded in sovereignty because they entirely miss technologies of power derived from techniques of discipline or confession. For example. I as a researcher might give someone who was a subject a right to review my interpretation to see if in fact I understood her or him. Yel, if one were to actually examine the interaction during the review, one would see all sorls of accounts, postures, and gestures on the part of both of us as we struggled over an acceptable interpretation. Furthermore, life in organizations is replete with the asymmetries of hierarchy and dividing practices. I might give both a worker and a manager a chance to review interpretations. Both would probably work to eliminate interpretations which make them look bad or which reveal strategies that they are trying to keep hidken. The worker his much less ability to keep her or his interpretations from manilgers -- who mest ofien engage in sludies -- than the manager has to keep her or his interpretations from workers. Thus, asymmetries of power which are tolially missed by the concept of rights have an cffect on the construction of interprelations. All of these technicuues for relatting do scrious damage to the ideat of a Iranscendental subject so crilical to membership validation and lo vallidalion llorough recognition anol honoring.

In some of lioucalult's latc interviews (Foucault 1982a. 1982h), lectures (Foucilult 1988:1, 1988c; Miller 1993), and books (Fouciault, 1988b, 199(1)), one finds evidence thall could suggest that Foucault may have at least assumed a Iranscendental subject in his new interest in the self. As Miller (1993) accounts Foucaull's Howison lecture at Berkeley, Foucault admils that he may have overly persisted in his reliance on Iechniques by which others work on the self. He could now see the importance of techniques that enable persons to work on their own bodics, souls, thoughts, and conduct to transform themselves, modify themselves, or act in a slate of perfection or happiness. "Perhaps in a different kind of world, with a different set of techniques for approaching the self, a human being might no longer feel compelled to punish itself .. and 'sacrifice' itself -- in order to hecome what one is" (Miller 1993:324).

Yet. a closer reading of a few passages from these later works suggest that Foucault is not giving credence to the concept of a transcendental subject with his emphasis on the art of existence. On the one hand, the art of existence for Foucault (1990h) means intentional and voluntary actions by which people seck to Iransform their lives into a work that carry cerlain aesthetic values and stylistic critcria. In the first part of this formulation, a person is acting "intentionally" and "voluntarily" in the currency of the transcendental subject. Yet, in the sccond part of the formulation, one is engaged in a practice that contains values and criteria. The practice itself is a device that is not power neutral. Practices involved in the art of existence are "modes of subjectivation." They mark out a substance for which one cares. They are modes by which ".. the individual cstablishes his relation to a rule and recognizes himself as obliged to put it to work" (Foucault 1990b:27). There is "cthical work" that one performs on oneself to comply with rules and to Iransform oneself into the clinicat subject of one's behavior. Foucault makes it plain in an interview that he does not sec the Greck alternative analyzed in these laler works as an alternalive which would liberate the sclf from self-incurred tutelage (Foucault 1982a:231):

No! I am not looking for an alternative; you can't find the solution of a problem in the solution of another problem raised at another moment by other people. You sce, what I want to do is not the history of solutions, and that's the reasons why I don't accept the word "alternative." I would like to do genealogy of problems . . . . My point is not that everything is bad, but that everything is dangerous, which is not exictly the same as had. 


\section{Method as Ruse}

A ruse is a gimmick or device used as a strategy or instrument. For Foucault, method can best be understood as a ruse rather than as a method which promises Iruth. In fact, trull from Foucault's viewpoint is produced by rules and relations for separating or dividing statements into the true or the false. The rules and relations of the idealist and of the realist epistemologies are disciplines and as such tame and normalize as surely as does discipline applied to prisoners. Truth itself is a ruse in the game of power/knowledge. By recognizing truth in this way, Foucault (1984:46) is able to raise his principle question: "How can the growth of capabilities he disconnected from the intensilication of power relations?" Because of his attempt to explore the capabilities in social practices without resorting to the power effects of truth about those capabilities, Foucault's method has been called an anti-method (Shiner 1982). As Keeley (1990) notes, Foucault is not interested in theorizing or in hypotheses. Instead, Foucault encourages a researcher to adopt an attitude of contestability, to apply analytic devices, and to explore possibilities.

In addition to bracketing the issue of truth with the use of ruse as method, Foucault adopts other strategies which are designed to unhinge the realist and idealist frameworks of truth. First, Foucault (1984) concentrates on specific instances with historical investigations in order to separate out from the contingencies that which makes us what we are and what we are no longer capable of being. By focusing on the historical and the specific, Foucault intends to reject the search for formal structures with universal value. Second, Foucault (1980) encourages one to concentrate on practices, that is, to concentrate on how things work at the on-going point of application. By focusing on practices, Foucault intends to reject inquiry at the level of conscious intentions or decisions. Third, Foucault (1980) encourages one to begin the analysis of power at the local level in the application of various practices to things, to the actions of others, and to actions on one's self. Only then can one conduç! an ascending analysis by exploring how local practices are.invested, colonized, and utilized by other practices. By focusing on the infinitesimal applications of techniques of relation. Foucault intends to reject an exclusive focus on large, centralized mechanisms as an explanation for phenomena. While Foucault (1980) encourages one to begin with the infinitesimal and then explore their colonization in an ascending analysis of power, Donnelly (1982) observes that Foucault fails to follow his own advice by showing how technologics such as discipline in the prison are analogous to the industrial setting without actually Iracing the process of diffusion. Finally, Foucault (1980) claims that one cannol achieve a perspective for fully knowing our historical limits. Theoretical and practical experience is always limited and determined. With no independent reality or transcendental subject which can be used as a measure, one is always in the position of beginning again. While each new study with realism and idealism represents a new approximation, each new study with method seen as ruse represents a new perspeclive. By recognizing methol as perspective. losucault intends to reject the foundational assumptions of iclealism and realism.

Even though looucault rejects foundational assumptions, he (Fouciall 1984:47) claims that his atpproach to method does not mean that ". . no work cill be done except in disorder and contingency." His method has its homogeneity, its systematicity, and its generality.

By homogeneity. Foucault (1984) means that one studies what people do and how they do it. In order to do this, Foucault examines practices as if they were techniques or devices. For example, one could look at a prictice as if it were an appatralus (Foucault 1980). That is, one could lonk at a practice as heing an cnscmble consisting of discourses, institutions, archilectural forms, regulatory decisions, law, administrative measures, scientific statements, moral propositions, etc. Then, one could try to identify the nature of the connections that can exist hetween the elements. Finally, and to the point, one could explore how these elements and their relation to each other set up or discourage certain lines of hehavior. Foucault deals with this last point by claiming that an apparatus has a stratcgic function (Foucault 1980) or is conditioned by stratcgy just as the apparatus also conditions stralegy (Foucault 1990a). For this reason. Donnelly (1982) has criticized Foucault for engaging in functional arguments or in denying hut requiring a transcendental subject to give meaning. However, as Cooke (1993a) demonstrates, if one stays on Foucault's horse and altends to the asymmetries in the apparatuses involved in practices, one can explore differential nutcomes set up hy practices without resorting to functions or needs or without needing a transcendental actor with a purpose. Another way Foucault explores how practices work is to focus on discourse with the idea of the episteme (Foucault 1972: 1980). The episteme is the apparatus which makes possible the scparation of what may be taken to be true from that which may not be characterized as true. Again, one is interested in exploring what discursive and non-discursive elements are related in what way to separate statements taken to he true from those not taken to he true.

By systematicity, Foucault (1984) identifies three broad areas of practical systems: relations of control over things, relations of aclions upon others, and relations with onesclf. For example, with respect to constituting ourselves as moral agents of our own actions, Foucault (1984, 1988a, 1988b, 1990a, 1990b) hegins by lonking at what part of the self or action is conceived as ethical substance. He then moves to explore modes of subjection by which people are invited or incited lo recognize moral obligations and means by which people can change themselves in order to hecome ethical subjects.

Finally, by generality, Foucaull (1984:49) means that his investigations are specilic and "... hear upon a material, an epoch, a body of determined praciices and discourses . . ." that ". . have continued to recur up to our time ...." Here, Foucault (1990a) is not only interested in identifying and analyzing strategic unities, he is interested in examining critical changes which reflect a reversal of relationships of forces. Since such a reversal is a complex 
restructuring of apparatuses, it must be described comparatively. Thus, Lewert and Gillan (1982) observe that Foucault structures his text with a "then" and a "now." First, Lewert and Gillan (1982) note that Foucault hegins every text and most sections with the description of an exceptional case which anchors what follows. For example, in Discipline and Punish, Foucault begins the book with the description of a torture and execution as a case to analyze the technology of punishment used by the king. Foucault (Lewert and Gillan 1982) then employs an oppositive structure -- c.g., then ... now -- to organize a comparison of the Iwo different apparatuses that mark the reversal of relationship of forces. This comparison aids in the exploration of the apparatuses and how they evoke or inhihit different lines of action. Again, in Discipline and Punish. Foucault's analysis of the use of punishment on the body of the condemned then is compared with the emergence and application of techniques of discipline borrowed from the military, the school, and the church and applied to the prison now. He finally explores how social science could emerge from the application of discipline to a confined population but could not emerge with the use of punishment on the hody of the condemned by the king. Thus, Foucault's analytic is applied to analyze how one set of apparatuses are displaced by another.

The method used by Foucault contains at least seven points of practice. First, Foucault (1984) encourages one to focus on what people do and how they do it. In order to examine practices. Foucault (1980) views them as if they were techniques or devices. Second, to identify practices, Foucault (1980, 1984) encourages one to explore how things are made problematic. Third, Foucault (1984) encourages one to explore what substances the practices posit and work on as a practical system. Specifically, Foucault contends that practices posit and work on things, the actions of others, and relations with oneself. Additionally, Cooke (1993b) has observed that relations themselves are objectified and worked on by social practices for constructing relationships. Fourth, Foucault (1991a, 199 /b) encourages one to break down practices into the elements which constitute them. The number of such elements are not given in advance but can be taken to be finite. Thus, "one has to proceed by progressive, necessarily incomplete saturation". (Frucault 199/h:77). Fifth, Foutcault (199/a, 199/b) encourages one to identify the nature of the connections that can exist among the elements and the lines of activity they set up or inhibit. For Foucault (199/b), practices have hoth prescriptive effects regarding what is to be done and codifying effects regarding what is to be known. Sixth, Foucault (1984, 199/a, 199/b) encourages one to examine critical changes in practices which constitute a reversal of relationships of force. Since such a reversal is a complex resiructuring of apparatuses, it must be described comparatively. Thus, Lemert and Gillan (1982) observe that Foucault structures his IexI with a "then" and a "now." Seventh, Foucault $(1979,1980,1984)$ encourages one to examine how practices circulate and are colonized by other practices.

Foucault's approach is similar to both the grounded theory approach to qualitative research (Strauss 1987; Charmaz 1988) and the participatory action research approach to the study of organizations (Whyte 1991). As with poucault, grouncled theory hegins hy examining what is going on and looks for whil can he delined and discovered rather that hy deducing a hypothesis from theory and then lesting it with data. Since one does not know in advance in greutnded theorry exactly what needs to be sampled, one explores. analyzes through developing theoretical categories and the relationships helween those calceories, and then uses theorelical galps to decide what needs to be simnpled nex 10 extend and lill in theory development. In a similar fashion, Foucault encourages one lo hegin by exploring where and how things are made problemalic. However, lic has a framework for exploring the problemalic. What practices are involved in making things problemalic? What substance do they creille and work on? The actions of others? The scir? Things? How do they work on them? What lines of action are encouraged or discouraged? Furthermore, Foucault encourages one to expand the enumeration of elcenents of praclices and relations among them rather than using categories as devices for collapsing distinctions. While theory development drives sampling in grounded theory, Foucault would recognize that a rescarcher works in a sel of practices. So, practices implicit in the setting which make things problemalic drive sampling. Different groups are on the receiving end or applying end of practices. They experience them as problematic from these difierent angles. The practices themselves close or open access to viewpoints and settings.

With the participatory action research approach, one actively works with memhers of an organizalion throughout the rescarch process. Like Foucault, one begins by discovering the problematic in an organization. The viewpoints of actors are not avoided but used to construct the picture of what is occurring. Unlike Foucault, one tests perceptions with members of organizations in participatory action research to clarify perceptions. For Foucault, such testing involves organizational practices that must he explored rather than transcendental actors that can be relied on for verification. In participatory action research, one develops with memhers of an organization a strategy 10 address the problematic through such a process. In other words, the research strategy itself can help to sel up a new line of cooperalive hehavior. Foucault himself was very much interested in exploring practices with an eye to new ways of acting. However. unlike participatory action research, the articulatioin of a set of values or social policy -- such as cooperation -- prohably inhibits effective political and ethical action from Foucault's (Gandal 1986) viewpoint. Since all practices are built on asymmetric apparatuses, all practices are dangerous. While Whyte's (1991) analyses of several case studies of participatory action research focused on two poltentially conflicting groups coming together in cooperation, such approaches, while setting up new lines of cooperation, represent potential danger to the union or to management. For example, Banks and Metzgar (1989) describe how participatory stritegics used by management to sel up conperation can be used to appropriate shop lloor knowledge and, in doing so, continue the process of deskilling workers. There are no utopian solutions. 
Foucault's method not only represents an approach to explore how social practices work, but it also represents a ruse or gimmick for social criticism. The melhod of social criticism for both the realists and the idealists rests on the traditional dichotomy of fact and value. The realists separate fact and value and traditional dichotomy of fact and value. The rest a value free picture of what is real to critique claims based on value. Here, value is disclaimed while the picture of the real plays the role of value. IJealists tend to collapse fact and value in the act of knowing and thereby reduce criticism to the rhetoric and politics of claim making.

With the ruse of the genealogy of power. Foucault combines fact and value through two different understandings of the term power. On the one hand, Berndison (1970) used the term power to essentially mean cause. Power is know in and exercised at the point of surmounting change and resistance. The appearance of permanence is created by overcoming the novel from moment to moment. On the other hand, Cooke (1990) has argued that power can be understood as a moral calcgory. Within the technology of sovereignty, the exercise of power implies the use and abuse of rights. Thus, power is a moral problem which requires remedies to redress wrongs.

By combining these two senses of power, Foucault is simultaneously engaging in social criticism as he engages in social analysis. On the one hand, Foucault (1979) is simply describing how enclosure, partitioning, coding, and ranking constructs the individual as an object. By examining how activity in controlled through the use of time tables, the temporal elaboration of acts, the correlation of the body and gesture, the exhaustive use of the body and acts, and system of signaling commands, Foucault is simply describing an ensemble of clements and how they encourage and regulate certain actions. On the other hand, he is describing the tools by which power is exercised on people: tools that expose and ensnare actions, tools than rank and judge, and tools that entice the next action. As Dreyfus and Rabinow (1982: 81) note, rules operate simultaneously for Foucault as descriptive regularities and as prescriptive operative forces.

Foucault's perspective has been criticized by many. Most of these criticisms rely on cither the realist model, the idealist model, or both. From the idealist perspective of the meaning giving subject, Giddens (1984) criticizes Foucault for turning the subject into an epiphenomenon of the tactics of power. Taylor (1984) criticizes Foucault for attributing strategic pallerns to a contex without attributing such strategic patterns to anyone's conscious plan. Bhaskar without attributing such strategic patterns to anyone's conscious plan. Bhaskar (1986) points out that actors intente strategic patterns of the actor could continue through the strategic palterns of the context even in the absence of the actor.

But, in a critique of Taylor, Patton (1989) notes that Taylor's concept of But, in a critique of Taylor, Patton (1989) notes that Ther huilt on capacitics. Patton demonstrates that power as capacity is prior to all other senses of power. In the tradition of the idealist model, Giddens, Taylor, and olher senses of power. In the tradition of the idealist model, Giddens, Taylor, and purnose is caused hy good reasons. However, gond reasons are parts of appiraluses and are lliemselves replete with asymmetries which cneourage certain fines of aclions and discourage others. The only way that power can be separaled froun the asymunctrics of apparaluses is to locate a principle of decision making in sone essence which is not modified by the apparaluses hy which distinctions are made and by which actions are exccuted. This is exacally what Foucault refuses (o) (lo. By focusing on social praclices, Foucault renders actors, purposes, acts. and scenes in terms of agency or incans (Conke 1993a).

Realists atlack Foucault's epistemology hy pointing out that practice implies a rcality separate from the praclice. Margolis (1986) notes that there catn be no practice without a recognition of a reality within the life of a practice. One is always scarching for the necessary within the contingent. Shapiro (1990) points out that science assumes a causal mechanism that operates independent of our ability to perceive it. Bhaskar (1986) observes that there are three levels of reality: the real, the actual, and the apparent. While our research practices alfect what is apparent, there is a reality that makes it possible to refine the efforts of our rescarch practices to more accurately approximalc the real. Unlike the realists. Foucault is unwilling to privilege any picture of reality as true because there is no way in separate knowledge from the practices used to establish it. At the same time, Cooke (1993a) has pointed out that Foucault at least avoids solipsism by the minimal realism of recognizing sources of recalcitrance and asymmetrics set up by other praclices. While one cannot claim a reality scparate from the apparaluses used to establish it as the realist would have one do, one can use Foucault to describe the apparatuses involved in practices and the consequences associated with those practices.

\section{Conclusions}

Rescarch method is a ruse. It is an apparatus which regulates what is discovered and the discourse about what is discovered. If one adopted the traditional realist strategy of reviewing literature, deducing hypotheses, and crealing and implementing a research design to answer a series of yes or no questions, one would have to know the apparatuses used in a setting and the distribution of those apparatuses. One would also have to use a serics of devices to reduce actors to ohjects and to control the scene in particular ways. It is highly unlikely that such power and control would be available to a resenrcher in a natural setting. Since Foucault recognizes that the realist perspective scts up potential conclusions and limits all other views before one ever begins a study, he encourages one to explore socia! practices at the point at which they are made problemalic. This does not mean that one is engaged in a melhod which avoids regulating discovery and discourse. It simply means that one cannot know what practices exist and how they are heing made problematic hefore the fact of exploring the practices.

Since Foucault's analysis leads one to set aside method as an estahlisher of Iruth in any foundationalist sense, what is the point of any description of method 
at all? First, lo look at a set of practices using Foucault's approach is to apply a systematic rescarch device. So, a description of method can be rendered. However, the method makes no claims to iruth. Second, even though Foucault continues his effort to unhinge the truth claiming business of method by avoiding extensive documentalion of his research (Lewert and Gillan 1982), documentalion is an important technology for constituting trust in the secondary relationship of agency between the researcher and the reader. While a description of gathering and disseminating information does not generate truth in any foundational sense, Shapiro (1987) notes that they do provide the reader with the conventions by which the study was done so the reader can evaluate the work done by the researcher. In other words, a description of method is a disclosure.

\section{References}

Agar, Michacl H. 1986. Speaking of Ethnography. Beverly Hills, CA: Sage. 1988. "Ethnography and Cognition." Pp. 68-77 in Contemporary Field Research: A Collection of Readings. Edited by R. M. Emerson. Prospect Heights, IL: Waveland Press, Inc.

Alwin. D. F. and J. A. Krosnick. 1985. "The Measurement of Values in Surveys: A Comparison of Ratings and Rankings." Public Opinion Research 49:535-552.

Babbie, Earl R. 1986. The Practice of Social Research. 4th ed. Belmont, CA: Wadsworth.

Banks, Andy and Jack Metzgar. 1989. "Participating in Management: Union Organizing on a New Terrain." Labor Rcsearch Review 8(2): 1-55.

Berndtson. Arthur. 1970. "The Meaning of Power." Philosophy and Phenomenological Research 31:73-84.

Best, John W. 1981. Research in Education. 4th ed. Englewood Cliffs, NJ: Prentice-Hall.

Bhaskar, Roy. 1986. Scientific Realism and Human Emancipation. London: Verso.

Charmaz., Kathy. 1988. "The Grounded Theory Method: An Explication and Interpretation." Pp. 109-126 in Contemporary Ficld Research: A Collection of Readings. Edited by R. M. Emerson. Prospect Heights, IL: Waveland.

Cooke. Marvin L. 1990. "A Critical Analysis of the Concept of Power: An Intcractionist Revelation of Its Moral Nature." Free Inquiry in Creative Sociology 18:121-126.

1992. "The Transformation of Clergy Markets in the Methodist Church: The Oklahoma Annual Conference from 1940 to 1980." Sociological Spectrum 12:183-216.
1993;. "Iimancipatory Practice and the Use of the Ruse of Agency and the Ontolugy of Actors and Scene in the Analysis of Structure." The Hermboldt Jomrmal of Secial Relarions 19:31-72.

19y3b. Deconstructing Trust and Distrust in the Workplace: A Foncendiam Analysis of Labor Relatems in an Electric Unility. Unpublished dectoral dissertatlion. Oklahoma State University. Stillwalter.

Denzin, Norman K. 1983. "Interprelive Interaclionism." Pp. 129-146 in Beyend Method. Fodited by G. Morgan. Beverly Hills: Sage. 1989a. Interprefive Inseractionism. Newbury Park, CA: Sage.

1989h. The Research Acs: A Theoretical Imtroduction to Sociological Meshods. 3rd ed. Englewond Clifrs, NJ: Prentice Hall. 190(). "The Sociological Imaginaltion Revisited." The Sociological Quaterly 31: 1-18.

Donnelly. Michacl. 1982. "Foucault's Genealogy of the Human Sciences." Ecomomy and Society 11:363-380.

Dreyfus, Huhert L. and Paul Rabinow. 1982. Michel Foucault: Beyond Strucfuralism and Hermeneutics. 2nd ed. Chicago: Universily of Chicago Press.

Duncan, Otis Dudlcy. 1984. Notes on Sncial Measurement: Historical and Critical. New York: Russell Sage Foundation.

Emerson, Rohert M. 1988. "Introduction." Pp. 1-16 in Comtemporary Field Research: A Collection of Readings. Edited by R. M. Emerson. Prospect Hcights, Il: Waveland.

Foucauli. Michel. 1965. Madness and Civilization: A History of Insanity in the Age of Reason. Translated hy R. Howard. New York: Random House. 1972. The Archaeology of Knowledge and the Discourse on Language. Translated by A. M. Sheridan Smith. New York: Pantheon Books.

1975. The Birth of the Clinic. New York: Vintage Bonks.

1979. Discipline and Punish, the Birth of the Prison. Translated hy $\Lambda$. Sheridan. New York: Vintage Books.

1980. Power/Knowledge. Selected Interviews and Other Writings. 1972-1977. Edited by C. Gordon. Translated by C. Gordon, L. Marshall, J. Mepham, and K. Soper. New York: Pantheon Books.

1982a. "On the Genealogy of Ethics: An Overview of Work in Progress." Pp. 229-252 in Michel Foucault: Beyond Structuralism and Hermeneutics. By H. C. Dreyfus and P. Rabinow. Chicago: University of Chicago Press.

1982b. "The Subject and Power." Pp. 208-226 in Michel Foucault: Beyond Structuralism and Hermeneutics. By H. C. Dreyfus and P. Rahinow. Chicago: Universily of Chicago Press. 1984. The Foucault Reader. Edited by P. Rabinow. New York: Pantheon Boroks.

1984:. "Technologics of the Self." Pp. 16-49 in Technologies of she Self: A Scminar with Michel Foucault.. Ediled by I. Martin, H. 
Gutman, and P. Hutton. Amherst: University of Massachusetts Press. 1988h. The Care of the Self. Translated by R. Hurley. New York: Vintage Books.

1988c. "The Political Technology of Individuals." Pp. 145-162 in Technologies of the Self: A Seminar with Michel Foucault. Ediled by L.

Martin, H. Gutman, and P. Hutton. Amherst: University of Massachusetts Press.

1990a. The History of Sexuality. Translated by R. Hurley. New York: Vintuge Books.

1990b. The Use of Pleasure. Translated by R. Hurley. New York: Vintage Books.

1991a. "Politics and the Study of Discourse." Pp. 53-72 in The Foucault Effect. Edited by G. Burchell, C. Gordon, and P. Miller. Chicago: University of Chicago Press.

1991b. "Questions of Method." Pp. 73-86 in The Foucault Effect. Edited by G. Burchell, C. Gordon, and P. Miller. Chicago: University of Chicago Press.

Gandal, Keith. 1986. "Michel Foucault: Intellectual Work and Politics." Telos 19(2):121-134.

Giddens, Anthony. 1984. The Constitution of Society. Berkeley: University of California Press.

Gulting, Gary. 1989. Michel Foucault's Archaeology of Scientific Reason. Cambridge: Cambidge University Press.

Habermas, Jurgen. 1984. The Theory of Communicative Action. Vol. I: Reason and the Rationalization of Society. Translated by T. McCarthy. Bosion: Beacon Press.

Jones, Gareth R. 1983. "Life History Methodology." Pp. 147-159 in Beyond Method. Edited by G. Morgan. Beverly Hills, CA: Sage.

Kant, Immanuel. 1963. On History. Translated by L. W. Beck. New York: Bobbs-Merrill.

Kecley, James F. 1990. "Toward a Foucauldian Analysis of International Regimes." Intenational Organization 44:83-105.

Lewert, Charles C. and Garth Gillan. 1982. Michel Foucault: Social Theory and Transgression. New York: Columbia University Press.

Lewis, David. 1991. "The Contemporary Human Resource Management Challenge to Industrial Relations." Pp. 82-99 in The Future of Industrial Relations. Edited by H. C. Katz. Ithaca, NY: ILR Press.

Margolis, Joseph. 1986. Pragmatism without Foundations: ReconcilingRealism and Relativism. Oxford: Basil Blackwell.

Miller, James. 1993. The Passion of Michel Foucault. New York: Simon \& Schuster.

Palton, Paul. 1989. "Taylor and Foucault on Power and Freedom." Political Studies 37:260-276.
Reed, Theodore L. 1978. "Organizational Change in the American Foreign Service, 1925-1965: The Utility of Cohorl Analysis." American Sociological Review 53:404-21.

Shiner, Larry. 1982. "Reading Foucault: Anti-Method and the Genealogy of Powcr-Knowledge." History and Theory 21:382-397.

Smircich, Linda. 1983. "Studying Organizations as Cullures." Pp. 160-172 in Beyond Method. Edited hy G. Morgan. Beverly Hills. CA: Sage.

Smith, John K. 1983. "Quantitative Versus Qualitative Rescarch: An Attempt to Clarify the Issuc." Educational Researcher 12(3): 6-13.

Smith, John K. and Lous Heshusius. 1986. "Closing Down the Conversation: The End of the Quantitative-Qualitative Depate Among Educational Inquirers." Educational Researcher 15(1): 4-12.

Smith, T. W. 1987. "That Which We Call Welfare by Any Other Name Would Smell Swecter." Public Opinion Research 51:75-83.

Strauss, Anselm L. 1987, Qualitative Analysis for Social Scientists. Cambridge: Cambridge University Press.

Taylor, Charles. 1984. "Fouculat on Freedom and Truth." Political Theory 12:152-183.

Weher, Max. 1958. The Protestant Ethic and the Spirit of Capitalism. Translated by T. Parsons. New York: Charles Scribner's Sons. 1978. Economy and Society. 2 vols. Edited by G. Roth and C. Wittich. Berkeley: University of California Press.

Whyte, William Foote (Ed.). 1991. Participatory Action Research. Newbury Park, CA: Sage. 